\title{
PERAN LEMBAGA PERADILAN SEBAGAI INSTITUSI PENEGAK HUKUM DALAM MENEGAKKAN KEADILAN BAGI TERWUJUDNYA PERDAMAIAN
}

\author{
(Judicial Institution Role as Law Enforcement Institution Upholding Justice for Peace)
}

\author{
Ismail Rumadan \\ Pusat Penelitian Hukum dan Peradilan Mahkamah Agung RI \\ Jalan. A. Yani Kav. 58 Jakarta Pusat \\ Email: ismailrdhan@gmail.com
}

Naskah diterima: 15 Maret 2017; revisi: 12 April 2017; disetujui: 18 April 2017

\begin{abstract}
Abstrak
Penegakan hukum di Indonesia tidak saling sinergi dalam mewujudkan keadilan. Hal tersebut disebabkan karena posisi dan kedudukan lembaga hukum dimana fungsi penyidikan dan penuntutan berada dibawah kekuasaan eksekutif, sementara fungsi mengadili dan memutus berada di bawah kekuasaan Mahkamah Agung, menyebabkan adanya kecenderungan untuk melindungi kepentingan institusinya masing-masing dibanding upaya penegakan hukum demi kepentingan publik. Sehingga yang menjadi fokus dalam kajian ini adalah apakah peran hakim dalam menjatuhkan putusan demi menegakkan hukum dan keadilan dapat mewujudkan kedamaian bagi masyarakat pencari keadilan. Kajian ini hendak dijawab dengan metode yuridis-filosofis melalui studi kepustakaan yaitu dengan melakukan kajian secara teoritis terhadap teori-teori keadilan dan dikaitkan dengan implementasi penegakan hukum pada institusi peradilan. Hasil kajian menunjukan institusi pengadilan sebagai lembaga yang dijamin indepensinya dalam menegakkan hukum dan keadilan masih dipengaruhi oleh kekuatan dan kekuasaan lain, terutama pengaruh kekuasaan eksekutif dan kekuatan politik, fungsi penegakan hukum oleh pengadilan belum sepenuhnya mandiri, sehingga tugas utama pengadilan untuk mewujudkan keadilan dan kedamaian ditengah masyarakat masih jauh dari harapan. Oleh karena itu perlu untuk diperkuat institusi pengadilan sebagai benteng terakhir pencari keadilan untuk menghadirkan suasana dan perasaan damai bagi pencari keadilan.

Kata Kunci: peradilan, hukum, keadilan
\end{abstract}

\begin{abstract}
The current law enforcement in Indonesia has no mutual synergy in realizing justice. This happens because of the arrangement of the legal institutions where the examination and prosecution function under executive power, while the judge function under Supreme Court power, which brings tendency for each institution to protect internal institution interest than law enforcement for public interest. This study focus on finding judge role to decide verdicts in order to enforce law and justice that will give peace for justice seeker community too. This research use juridical and philosophical method through library studies on justice theories which then being associated with the law enforcement in Judicial institutions. This study shows that judicial institutions as guaranteed independent institution in enforcing law and justice still being influenced by another strength and power, especially executive and political power. Law enforcement function is not fully independent yet, so judicial institution main task and function for realizing justice and peace for community still short in expectation. Therefore judicial institutions need to be strengthened as the last fort for justice seeker to realize peace for community.
\end{abstract}

Keywords: judicial institutions, law, justice 


\section{A. Pendahuluan}

Penegakan keadilan dalam kehidupan bermasyarakat memiliki arti penting dalam salah satu upaya membangun peradaban bangsa yang tinggi dan bermartabat. Tidak akan maju peradaban dari suatu bangsa apabila tidak didasarkan atas peri kehidupan berkeadilan. Keadilan adalah tujuan akhir dari sebuah sistem hukum, yang terkait erat dengan fungsi sistem hukum sebagai sarana untuk mendistribusikan dan memelihara suatu alokasi nilai-nilai dalam masyarakat, yang ditanamkan dengan suatu pandangan kebenaran, yang secara umum merujuk kepada keadilan. ${ }^{1}$

Terkadang hukum positif tidak sepenuhnya menjamin rasa keadilan, dan sebaliknya rasa keadilan seringkali tidak memiliki kepastian hukum, sehingga komprominya adalah bagaimana agar hukum positif yang ada selalu merupakan cerminan dari rasa keadilan itu. Keadilan ini adalah hal yang paling mendasar bagi bekerjanya suatu sistem hukum. Sistem hukum tersebut sesungguhnya merupakan struktur atau kelengkapan saja untuk mencapai konsep keadilan yang telah disepakati bersama. ${ }^{2}$

Sistem hukum di mana pun di dunia ini, keadilan selalu menjadi objek perburuan, khususnya melalui lembaga pengadilannya. Dari pengamatan terhadap sistem hukum di dunia, hampir tidak ada negara yang benar-benar telah puas dengan sistem hukum yang digunakannya. Oleh karena itu, perombakan, pembaruan atau reform, dapat kita lihat terjadi dari waktu ke waktu di berbagai negara. Bahkan, Amerika Serikat (AS) sebagai negara yang dianggap maju dalam pelaksanaan demorasi, hingga saat ini masih terus menginginkan pembaruan. Pembaruan tersebut datang tidak lain karena negara yang bersangkutan merasa ada yang kurang benar pada sistem yang dipakainya untuk berburu keadilan tersebut. Di AS, ketidakpuasan tersebut antara lain dirumuskan dalam berbagai ungkapan yang dramatis, seperti the collapse of the American criminal justice system (ambruknya sistem peradilan pidana Amerika) dan the expensive failure of the American criminal trials (kegagalan yang mahal dari pengadilan pidana AS). Ternyata keambrukan tersebut berhubungan juga dengan fokus yang tidak jelas mengenai keadilan. $^{3}$

Sistem atau penyelenggaraan hukum di Indonesia dewasa ini dalam suasana keambrukan. Antara satu subsistem dengan subsistem penegak hukum yang lain tidak saling sinergi dalam menegakkan keadilan, faktor yang paling mendasar adalah posisi dan kedudukan lembagahukum dalammenegkan keadilan dalam konteks menjalankan fungsi yudikatif berbeda antara satu subsistem dengan susbsistem yang lain. Fungsi penyidikan dan penuntutan berada dibawah kekuasaan eksekutif, sementara fungsi mengadili dan memutus berada di bawah kekuasaan Mahkamah Agung. Sehingga berimplikasi pada penegakan hukum itu sendiri dalam tataran praktis apabila penegakan hukum itu bersinggungan dengan kepentingan masing-

\footnotetext{
Lawrence M.Friedman, The Legal System : A Social Science Perspective, Rusell Sage Foundation, New York 1975, hlm 17-18.

2 Satjipto Rahardjo, Membedah Hukum Progresif, Kompas, Jakarta, 2007, hlm 270, dalam Amelinda Nur Rahmah, Keadilan di Dalam Lembaga Hukum, http://www.kompasiana.com/amelindanurrahmah/keadilan-di-dalamlembaga-hukum, (diakses 9 Februari, 2017).

3 Amelinda Nur Rahmah, Keadilan di Dalam Lembaga Hukum, Ibid.
} 
masing institusi, kepentingan untuk melindungi institusi lebih penting ketimbang kepentingan untuk menegakkan hukum demi kepentingan publik. Dalam contoh kasus yang pernah terjadi pada saat kontroversi antara polisi dan KPK maupun kejaksaan dalam hal penegakan hukum korupsi yang dikenal dengan kasus cicak versus buaya.

Hal yang paling sering disoroti dan menjadi fokus dalam kajian ini adalah kinerja pengadilan atau sistem peradilan kita yang jauh dari memuaskan yang berunjung kepada rasa kenyamanan dan kebahagiaan para pencari keadilan. Tetapi sebetulnya, fokus keambrukan itu lebih luas daripada hanya di pengadilan. Berdasarkan pengalaman di negara lain, fokus perhatian ingin diarahkan pada konsep kita tentang keadilan dan apa yang perlu diperbaiki. Sejak hukum modern memberi peluang besar terhadap berperannya faktor prosedur, atau formalitas, atau tata cara dalam proses hukum, perburuan terhadap keadilan menjadi sangat rumit. Indonesia dewasa ini berada di tengah-tengah krisis dan keterpurukan hukum. Kerusakan dan kemerosotan dalam perburuan keadilan melalui hukum modern disebabkan permainan prosedur, ${ }^{4}$ yang menyebabkan timbulnya pertanyaan "apakah pengadilan itu tempat mencari keadilan atau kemenangan?

Persepsi penegak hukum maupun masyarakat selama ini terhadap proses penegakan hukum di Pengadilan adalah terkait atau berhubungan dengan menang-kalah, sehingga pengadilan yang sesungguhnya memiliki peran mendamaikan $^{5}$ melalui penjatuhan putusan yang adil sulit untuk diwujudkan. Keadilan dan kedamaian adalah dua hal yang saling berkaitan, bahkan boleh dikatakan ukuran keadilan dalam penegakan hukum adalah bagaimana ekspresi dan respon masyarakat terhadap penjatuhan vonis kedilan tersebut, sebab keadilan dalam konteks penegakan hukum selama ini adalah atas dasar tafsiran dan persepsi penegak hukum itu sendiri, baik dalam konteks penegakan hukum pubik (tuntutan keadilan secara umum dalam konteks hubungan masyarakat dengan pemerintah) maupun penegakan hukum secara perdata (antara orang perseorangan dengan orang perseorangan yang lain dalam hubungan privat). Sehingga menjadi pertanyaan apakah peran hakim dalam menjatuhkan putusan demi menegakkan hukum dan keadilan dapat dapat mewujudkan kedamaian bagi masyarakat pencari keadilan?

\section{B. Metode Penelitian}

Metode pendekatan yang digunakan untuk mengkaji dan menganalisis permasalahan dalam tulisan ini dengan menggunakn pendekatan yuridis-filosofis sebab aspek atau tema kajian yang menjadi fokus perhatian adalah mengenai permasalahan hukum dalam implementasinya pada institusi peradilan dalam mewujudkan keadilan dan kedamaian bagi pencari keadilan. Oleh karena itu metode kajian melalui studi kepustakaan dengan melakukan kajian secara teoritis terhadap teori-teori keadilan dalam kaitannya dengan penegakan hukum pada institusi peradilan. Oleh karena itu, seluruh argumentasi dan hasil analisis dilakukan

$4 \quad$ Dalam konteks penegakan hukum tindak pidana korupsi misalnya, dalam beberapa kasus tertentu seperti kasus Bank Century, maupun kasus BLBI, secara materiil terdapat adanya kerugian keuangan negara, namun hanya karena ada permainan secara prosedur dan formil, akhirnya kasus tersebut tidak kunjung ditegakkan.

5 Lihat Ketentuan Pasal 130 HIR dan Pasal 145 RBg 
secara kualitatif serta kesimpulan yang didapat didasarkan pada studi literatur berkaitan dengan tuntutan keadilan yang memiliki hubungan yang sangat erat dengan penegakan hukum. Bahkan secara lebih tegas dapat dikatakan bahwa hukum tidak memiliki tujuan pada dirinya sendiri. Hukum hanya merupakan instrumen untuk mencapai keadilan. Setiap kali hakim memutuskan sebuah perkara, hakim selalu memulainya dengan kalimat demi keadilan.

\section{Pembahasan}

\section{Memaknai Keadilan dalam Penegakan Hukum}

Makna keadilan telah menjadi pokok pembicaraan serta perdebatan secara serius sejak awal munculnya filsafat Yunani, memiliki cakupan makna yang sangat luas, mulai dari yang bersifat, religius, etik, filosofis, hukum, sampai pada makna keadilan sosial. Dalam konteks hukum, pada prinsipnya keadilan merupakan hal yang senantiasa dijadikan topik utama dalam setiap penyelesaian masalah yang berhubungan dengan penegakan hukum. Banyaknya kasus hukum yang tidak terselesaikan karena ditarik ke masalah politik. Kebenaran hukum dan keadilan dimanipulasi dengan cara yang sistematik sehingga peradilan tidak menemukan keadaan yang sebenarnya. ${ }^{6}$ Kebijaksanaan pemerintah tidak mampu membawa hukum menjadi "panglima" dalam menentukan keadilan, hukum justru diposisikan sebagai alat kekuasaan. Atau bahkan hukum dan keadilan menjadi objek yang mahal, hukum dan keadilan hanya dimiliki oleh orang-orang atau kelompok yang memiliki modal dan mampu.
Sebagai contoh dapat di telusuri beberapa kasus yang menciderasi rasa keadilan masyarakat. Misalnya dalam kasus penahanan terhadap Asyani, nenek berusia 63 tahun karena dituduh mencuri 38 papan kayu jati di Situbondo, Kemudian dalam kasus nenek Minah yang dituduh mencuri 3 (tiga) buah kakao terpaksa diputus bersalah, dan dihukum 1,5 bulan penjara. Demikian juga dalam kasus-kasus yang lain seperti kasus, Manisih dan Sri Suratmi yang divonis bersalah karena mengambil buah rando senilai Rp 12.000,- dan kasus Surati sukarno dan kawan-kawan yang dituduh menyalagunakan rumah dinas Perum Pegadaian.

Kasus-kasus tersebut di atas memperkuat argumen bahwa hukum dan keadilan sesungguhnya tidak berpihak bagi kelompok yang lemah. Lain halnya dengan beberapa kasus yang belakangan ini terjadi seperti kasus yang melibatkan Gubernur DKI Basuki Cahaya Purnama, yang terindikasi terlibat dalam beberapa kasus korupsi, seperti kasus Sumber Waras dan Transjakarta, namun hingga kini tidak pernah ditindaklanjuti oleh penegak hukum, demikian juga dalam kasus BLBI. Kondisi ini menggambarkan bahwa kepastian hukum dan keadilan dalam kebijakan hukum yang diambil pemerintah telah menimbulkan ketidakadilan bagi sebagian tersangka/terdakwa serta masyarakat luas, bahkan tampak diskriminatif.

Istilah keadilan senantiasa dipertentangkan dengan istilah ketidakadilan. Di mana ada konsep keadilan maka disitu pun ada konsep ketidakadilan. Biasanya keduanya disandingkan dan dalam konteks kajian hukum ada banyak contoh ketidakadilan yang merupakan antitesa dari keadilan dalam bidang hukum misalnya

6 Inge Dwisvimiar, Keadilan Dalam Perspektif Filsafat Ilmu Hukum, jurnal dinamika Hukum, vol; 1, No. 3 September 2011. 
di Indonesia, seperti : ketidakadilan terhadap rakyat kecil, ketidakadilan pemberitaan, ketidakadilan dalam distribusi bantuan bagi masyarakat miskin, ketidakadilan gender dalam masyarakat daerah, ketidakadilan dalam penegakan hukum, dan sebagainya. ${ }^{7}$

Antara keadilan dan ketidakadilan adalah dua kategori yang saling berkaitan satu dengan lainnya, seperti ungkapan Roxanne Varzi, "there is no justice without crime" (tidak pernah ada keadilan tanpa didahului oleh suatu tindak kejahatan) yang dipresepsikan sebagai suatu bentuk ketidakadilan. ${ }^{8}$ Bahkan sesuatu yang tidak biasa dalam memaknai keadilan, yang terkait dengan substansi yang ada di dalamnya. Keadilan akan dibenturkan dengan keraguan dan ketidakadilan, bahwa sesungguhnya keadilan tidak akan berdaya tanpa ketidakadilan dan keraguan. ${ }^{9}$

Keadilan, sering diartikan sebagai suatu sikap dan karakter. Sikap dan karakter yang membuat orang melakukan perbuatan dan berharap atas keadilan adalah keadilan, sedangkan sikap dan karakter yang membuat orang bertindak dan berharap ketidakadilan adalah ketidakadilan. Oleh karena itu keadilan dalam perspektif islam menyaratkan bahwa keadilan bukanlah tujuan dari hukum, hukum tidak hendak menuju keadilan, jika hukum hendak menuju keadilan atau mencapai keadilan berarti hukum Islam tidak bernuansa keadilan, karena masih hendak ditujunya. Keadilan dalam perspektif hukum Islam adalah bersama keadilan, dan beserta moral pelaku hukum, karena perintah Islam terkait dengan perilaku penegak hukum itu sendiri untuk berlaku adil, sebab perilaku adil tersebut lebih mendekat kepada nilai ketakwaan. ${ }^{10}$

Berbeda halnya dengan teori hukum yang kita pahami saat ini bahwa, hukum diadakan sebagai upaya untuk meraih sebuah keadilan, dalam konteks ini maka, terdapat jarak atara hukum dan keadilan. Ketika manusia menggerakkan hukum, esensi hukum tidak berisi keadilan, karena keadilan itu sendiri baru dicapai atau dituju oleh hukum, oleh sebab itu tidak akan pernah sampai hukum itu jika tujuan yang hendak dicapai tidak disertai dengan keadilan itu sediri. Sehingga logis bila dikatakan hukum itu tidak pernah adil, karena tidak pernah sampai pada tujuannya. ${ }^{11}$

Secara umum dikatakan bahwa orang yang tidak adil adalah orang yang tidak patuh terhadap hukum (unlawful, lawless) dan orang yang tidak fair (unfair), maka orang yang adil adalah orang yang patuh terhadap hukum (lawabiding) dan fair. Karena tindakan memenuhi/mematuhi hukum adalah adil, maka semua tindakan pembuatan hukum oleh legislatif sesuai dengan aturan yang ada adalah adil. Tujuan pembuatan hukum adalah untuk mencapai kemajuan kebahagiaan masyarakat. Maka, semua tindakan yang cenderung untuk memproduksi dan mempertahankan kebahagiaan masyarakat adalah adil. ${ }^{12}$

\footnotetext{
Inge Dwisvimiar, Ibid.

8 Herman Bakir, Filsafat Hukum, Tema-Tema Fundamental Keadilan dari Sisi Ajaran Fiat Justitia Ruat Caelum, (Yogyakarta: Pustaka Pelajar,2015), hlm. 25.

9 Anthon F. Susanto, "Keraguan dan Ketidakadilan Hukum (Sebuah Pembacaan Dekonstruktif)", Jurnal Keadilan Sosial, Edisi 1 (2010), hlm. 23.

10 Fokkey Fuad Wasitaatmadja, Filsafat Hukum, Akar Religiositas Hukum, (Jakarta: Prenadamedia Group, 2015), hlm. 47.

11 Ibid.

12 Inge Dwisvimiar, Op.cit.
} 
Ukuran keadilan sebagaimana di singgung di atas sebenarnya menjangkau wilayah yang ideal atau berada dalam wilayah cita, dikarenakan berbicara masalah keadilan, berarti sudah dalam wilayah makna yang masuk dalam tataran filosofis yang perlu perenungan secara mendalam sampai hakikat yang paling dalam, bahkan Kelsen menekankan pada filsafat hukum Plato, bahwa keadilan didasarkan pada pengetahuan perihal sesuatu yang baik. ${ }^{13}$ Pengetahuan akan hal yang baik secara fundamental merupakan persoalan di luar dunia. Hal tersebut dapat diperoleh dengan kebijaksanaan. ${ }^{14}$

Keadilan menjadi bagian yang tidak terpisahkan dari tujuan hukum itu sendiri, di samping kepastian hukum dan kemanfaatan. Mensikapi adanya beberapa permasalahan (baca: kasus) hukum yang terjadi di negara Indonesia yang kemudian dituangkan dalam beberapa putusan hakim, ${ }^{15}$ sehingga membawa pada satu perenungan bahwa terminologi keadilan yang notabene ada dalam kajian filsafat dapatkah dijadikan sebagai bagian utama dalam pencapaian tujuan hukum, mengingat konsep keadilan yang bersifat abstrak sehingga diperlukan pemahaman dalam filsafat ilmu hukum yang akan menjelaskan nilai dasar hukum secara filosofis sehingga dapat membangun hukum yang sebenar-benarnya.
Merefleksikan arti keadilan dalam konteks mencari kebenaran dari suatu persoalan yang beragam di dalam kehidupan berbangsa dan bernegara, tentu tidak terlepas dari asumsi-asumsi yang berdimensi subjektivitas, egosentris, primordialisme, dan lain sebagainya. Sehingga untuk menetapkan suatu hukum (putusan pengadilan) bagi masyarakat pencari keadilan, selalu terbeban isu-isu yang menegaskan putusan pengadilan itu sendiri. Namun demikian, untuk mengurangi "beban ketidakadilan" bagi suatu putusan pengadilan yang sudah terpostulasi sebagai "keadilan hukum dalam suatu negara", perlu suatu sistem hukum, perangkat hukum, dan budaya hukum yang bersinergi secara positif (meminjam istilah M. Friedman), agar citra putusan pengadilan sebagai cermin rasa keadilan terwujud di dalam suatu negara hukum. Tanpa itu, khususnya budaya hukum (recht culture) yang terefleksi melalui perilaku sehari-hari masyarakat dan aparat hukum, maka hukum (putusan pengadilan) tidak lebih dari sekedar assesoris tanpa makna.

\section{Independensi Peradilan dalam Menegakkan keadilan}

Independensi kekuasaan lembaga peradilan tidak dapat dipisahkan dari perdebatan teoritik tentang pemisahan kekuasaan (separaion of

W. Friedmann, 1990, Teori dan Filsafat Hukum, (Jakarta: PT. Rajawali Press), hlm. 118.

14 Filsafat, dalam satu pengertiannya diartikan sebagai suatu kebijaksanaan yang rasional dari segala sesuatu, disamping diartikan sebagai suatu sikap dan pandangan, serta suatu proses kritis dan sistematis dari segala pengetahuan manusia. Lihat Maryanto, "Refleksi dan Relevansi Pemikiran Filsafat Hukum Bagi Pengembangan Ilmu Hukum", Jurnal Hukum, Fakultas Hukum Universitas Islam Sultan Agung Semarang, Vol. 13 (1) (2003), hlm. 52-5.

15 Sejatinya hakim adalah "wakil Tuhan" yang bertugas untuk menyampaikan kebenaran dan keadilan, maka setiap putusan hakim wajib mencantumkan "Demi Keadilan Berdasarkan Ketuhanan Yang Maha Esa". Adanya hakim sebagai "wakil Tuhan" dilatarbelakangi secara historis, dalam teori hukum dan negara, suara Tuhan tersebut dalam konteks renungan kefilsafatan tentang kedaulatan negara atau raja, melahirkan filsafat kedaulatan Tuhan. 
powers), ${ }^{16}$ karena pemisahan kekuasa dari cabang-cabang kekuaaan negara dimaksudkan untuk menjamin adanya independensi keuasaan lemaga peradilan, sekaligus untuk menjamin terlaksananya kebebasan politik (political liberty) anggota masyarakat dalam negara. ${ }^{17}$ Adanya jaminan kekuasaan lembaga peradilan yang independen merupakan suatu elemen penting dari konsep negara hukum. ${ }^{18}$

Lembaga peradilan memiliki peranan penting dalam implementasi konsep negara hukum saat proses demokrasitisasi, terutama dalam kondisi transisi dari sistem politik yang otoriter ke arah masyarakat yang demokratis, transparan, terlihat dari peran lembaga peradilan dalam penyalahgunaan proses peradilan untuk kepentingan masyarakat, karena peradilan merupakan institusi pelaksana konstitusi, perlindungan hak asasi dan jaminan atas prosedur-prosedur yang adil dan demokratis untuk menjamin adanya kepastian dan keadilan bagi setiap pencari keadilan. Dalam konteks yang ideal, dalam menjalankan fungsinya peradilan, para hakim tidak hanya menengahi konflik antara elit politik atau lebih berpihak kepada pemegang kekuasaan, tetapi lebih pada bagaimana untuk mencegah dan menghindari setiap pelaksanaan kekuasaan pemerintahan yang tidak adil dan demokratis.
Faktor kebebasan hakim sebagai syarat untuk terciptanya suatu putusan pengadilan yang adil dan tidak memihak (impartial), selain memuat implikasi yang berkaitan dengan undangundang, juga memuat implikasi yang berkaitan dengan dedikasi hakim itu sendiri. Dalam aspek jaminan undang-undang terhadap hakim yang memeriksa dan memutus suatu perkara, adalah tergantung bagaimana kemauan dan arah politik yang berlangsung di dalam suatu negara, sebagaimana yang terjadi dengan pergeseran kekuasaan kehakiman di Indonesia. Tetapi aspek dedikasi hakim dalam kebebasannya untuk memeriksa dan memutus suatu perkara, akan sangat tergantung pada nilai atau kualitas moral dan etika sang hakim sendiri. Artinya, jaminan kebebasan hakim yang diberikan oleh undangundang tidak akan menghasilkan citra keadilan dalam masyarakat apabila hakim menyalahgunakan prinsip kebebasan tersebut di dalam memutuskan suatu perkara yang dihadapinya. Dengan demikian, jelaslah bahwa konsep kebebasan hakim yang dianut di dalam undang-undang tersebut adalah kebebasan hakim yang bertujuan untuk menegakkan hukum dan keadilan, dan bukannya kebebasan hakim yang diarahkan untuk menegakkan kekuasaan. Dengan kata lain, kebebasan hakim ialah untuk menegakkan rule of law dan bukannya law of the ruler.

16 Montesquieu, The Spirit of The Law, transleted by Thomas Nugent, (Newyork: Hafner Press, 1949 ), hlm. 151. sebagaimana dalam Ahmad Mujahidin, Peradilan Satu Atap di Indonesia, (Bandung: Refika Aditama, 2007), hlm. 45.

17 Bagir Manan, "Organisasi Peradilan di Indonesia", dalam makalah Penataran Hukum Administrasi Tahun 1997/1998, Pelaksanaan Program Kerjasama Hukum Indonesia-Belanda, Penyelenggara Fak. Hukum Airlangga, Surabaya, 12 Februari, 1998, hlm. 2.

18 Dalam kepustakaan Indonesia istilah negara hukum merupakan terjemahan langsung dari rechtsstaat. Hal ini antara lain seperti yang dikemukakan oleh oleh Notohamidjojo yang menyebutkan "dengan timbulnya gagasan pokok yang dirumuskan dalam konstitusi Abad XIX itu maka timbul juga istilah negara hukum atau rechtsstaat". Sementara Muhammad Yamin menggunakan istilah Negara hukum sama dengan rechtsstaat atau government of law. Lihat, Mohamad Yamin, Proklamasi dan Konstitusi Republik Indonesia, Ghalia Indonesia, Jakarta, 1982, hlm. 72. 
Menanggapi hakikat kebebasan hakim yang sudah diperdebatkan sejak awal pembentukan Undang-Undang Nomor 14 Tahun 1970 tentang Ketentuan-Ketentuan Pokok Kekuasaan Kehakiman, Prof. Seno Adji memberikan jawaban (respon) terhadap kritik-kritik yang disampaikan oleh beberapa ahli hukum, bahwa Kebebasan Hakim baginya, bukan sekedar soal Trias Politica, bukanlah soal "separation des pouvoir"; ia bukanlah soal isolasi yang mutlak dan complete antara suatu bagian dengan yang lain. la sekedar merupakan suatu "distinction of powers", suatu division of powers antara kekuasaan-kekuasaan itu; ia menggambarkan dan menentukan suatu area dengan lingkungan kewenangannya, yang tidak boleh dilanggar atau dimasuki kekuasaan lain. Trias Politica dalam bentuk aslinya dan dalam interprestasinya yang ekstrim, bahwa harus ada suatu isolasi yang total antara ketiga kekuasaan, telah lama ditinggalkan. Bagaimanapun juga dalam pengertian luas, bahwa prinsip kekuasaankekuasaan itu harus ada dalam tangan yang berbeda-beda dalam "distinct hands", tidak dalam satu tangan sehingga dapat diterima oleh konstitusi-konstitusi modern. Dan salah satu maksud konstitusionalisme adalah, bahwa pengadilan itu harus bebas dari pengawasan pengaruh dan campur-tangan dari kekuasaan lain-lain." ${ }^{19}$

Bila kita memperhatikan karakteristik dunia peradilan di Indonesia, ada dua masalah pokok yang perlu mendapatkan perhatian, yaitu mengenai masalah "kebebasan hakim" dan "kekebalan hakim", sebagai suatu masalah yang cukup dilematis dalam penegakan hukum dan keadilan. Asumsi tentang kemungkinan adanya korelasi antara kebebasan dan kekebalan hakim, bukan sesuatu yang berlebihan apabila dikaitkan dengan citra dunia peradilan yang semakin buram dari waktu ke waktu. Sebab, ketika hakim ternyata melakukan penyimpangan terhadap perkara yang diputusnya, hakim dapat saja berkelit atau berlindung di balik makna kebebasan hakim tersebut, sehingga hakim seakan-akan kebal terhadap tuntutan hukum. Belum ada ketentuan atau undang-undang yang dapat menjerat perilaku hakim yang sengaja "bermain" hukum untuk memenangkan salah satu pihak berperkara, dan disinilah akan teruji asas kebebasan dan kadar etika atau kualitas moral seorang hakim. Bagaimana dampak kebebasan hakim menjadi sorotan dalam kajian pertanggungjawaban hukum sang hakim terhadap kesalahan atau penyimpangan yang dilakukannya, terlihat dari beberapa pendapat ahli hukum.

Dikalangan IImu Hukum kita mencatat pendapat beberapa Sarjana Hukum sepertinya Meyers, L.A. Donker, B.M. Telders, J.R. Stelinga dan yang lainnya pada umumnya berpendapat, bahwa apa yang tersebut dalam ketentuan pasal 1365 BW tidaklah dapat diterapkan terhadap hakim yang salah dalam melaksanakan tugasnya di dalam bidang peradilan. Sehingga dalam hal ini oleh Mahkamah Agung dapat disimpulkan bahwa Negara tidak dapat dipertanggungjawabkan atas kesalahan hakim dalam melaksanakan tugasnya dalam bidang peradilan. Hal tersebut diakui oleh Yurisprudensi (vide putusan H.R, 3 Desember 1977). Konsekuensi atas tidak dapatnya masyarakat menuntut atau menggugat "perbuatan melawan hukum" (onrechtmatigedaad eks

19 Nanda Dewantara, Masalah Kebebasan Hakim Dalam Menangani Suatu Perkara Pidana. Cetakan Kedua. (Jakarta: Aksara Persada Indonesia, 1987), hlm. 29 
pasal $1365 \mathrm{BW}$ ) dari seorang hakim yang telah "memanfaatkan" perkara yang diputusnya, maka selayaknyalah hakim ditundukkan secara tegas terhadap ketentuan hukum yang mengikat dirinya dalam memeriksa dan memutus perkara. Sifat kebebasan hakim itu merupakan suatu kebebasan yang diberi batas-batas oleh undang-undang yang berlaku, sebab hakim diberi kebebasan hanya seluas dan sejauh hakim dengan keputusannya itu untuk dapat mencapai suatu keadilan dalam menyelesaikan suatu perkara; dan pada akhirnya, tujuan hakim diberi kebebasan itu ialah untuk mencapai Negara Hukum Republik Indonesia.

Dapatlah disimpulkan, bahwa independensi atau kebebasan Hakim bukan kebebasan yang mutlak, melainkan "kebebasan yang terikat/terbatas" (gebonden vrijheid). Di samping keterikatan terhadap undang-undang (yang notabene masih debatable), keunikan pertanggungjawaban hakim dalam sistem hukum di Indonesia adalah melalui apa yang disebut dengan "pertanggungjawaban religi". Tugas hakim di Indonesia masih dibebani syarat bathiniyah dalam menjalankan tugas keadilan oleh undang-undang, yang karena sumpah jabatannya hakim tidak hanya bertanggungjawab kepada hukum, kepada diri sendiri, dan kepada rakyat, akan tetapi juga bertanggungjawab kepada Tuhan Yang Maha Esa, yang dalam undang-undang dirumuskan dengan ketentuan bahwa peradilan dilakukan "Demi Keadilan Berdasarkan Ketuhanan Yang Maha Esa".

Dapat diakui bahwa intervensi terhadap hakim tentu tidak berdiri sendiri tanpa adanya faktor lain yang turut ambil bagian. Sebab,
Mahkamah Agung sebagai lembaga tinggi, juga bergerak di ruang yang tidak hampa politik dan ekonomi tentu saja dapat dipengaruhi oleh kekuasaan lain, maupun dipengaruhi oleh pengaruh-pengaruh politik dan uang. Tetapi bukan berarti bahwa hal tersebut dapat dijadikan alasan untuk adanya intervensi (eksternal dan internal) terhadap kebebasan hakim. Hakim pada khususnya, dan lembaga peradilan pada umumnya, diharapkan memiliki peran sentral dalam penegakan hukum ditengah terik ulur kepentingan politik dan ekonomi. Karena itulah, reformasi hukum terutama reformasi penegakan hukum, yang dilakukan tanpa reformasi badan peradilan akan sia-sia belaka. Reformasi badan peradilan di sini dimaksud mencakup perubahan-perubahan agar lebih transparan dan mudah diawasi, agar integritas hakim benar-benar terpelihara, dibarengi profesionalisme nurani untuk menghayati nilainilai keadilan dalam penegakan hukum. ${ }^{20}$

\section{Integritas Putusan Hakim dalam menegakkan keadilan}

Sejalan dengan penjelasan terkait dengan independensi lembaga peradilan, pertanyaannya kemudian adalah, bagaimana usaha mewujudkan putusan hakim yang berkualitas sebagai representasi lembaga peradilan yang mencerminkan rasa keadilan, yang pada gilirannya juga menjadi salah satu komponen terwujudnya badan peradilan yang berkualitas menuju pada keunggulan peradilan (court excelllence).

Putusan berkualitas mencerminkan kemampuan hakim di dalam memutus perkara. Otoritas memutus perkara ada pada hakim

20 Antonius Sujata, Reformasi Dalam Penegakan Hukum, (Jakarta: Djambatan, 2000), hlm. 264. 
sebagai pemegang kekuasaan kehakiman yang dijamin kemerdekaannya oleh Undang_Undang Dasar Tahun 1945. Dalam pelaksanaan kekuasaan kehakiman antara "Putusan" dan "Hakim" merupakan dua hal yang tak terpisahkan, karena putusan pengadilan adalah produk hakim maka putusan berkualitas mencerminkan hakim yang berkualitas. ${ }^{21}$

Banyak teori tentang bagaimana mewujudkan putusan hakim yang berkualitas, namun bagi pencari keadilan yang mendambakan keadilan hukum. Terhadap perkaranya pada hakim, putusan hakim yang berkualitas baginya tidak lain hanyalah putusan yang dapat mewujudkan keadilan atau putusan yang mencerminkan rasa keadilan yang dapat dilaksanakan dan dapat diterima atau memuaskan pencari keadilan.

Terdapat dua persoalan mendasar dalam hal ini yaitu bagaimana mewujudkan putusan berkualitas dan bagaimana mewujudkan keadilan hukum dalam putusan. Beberapa persoalan dapat menjadi kendala untuk mewujudkan putusan berkualitas dalam proses penegakan hukum oleh badan peradilan, karena "menegakkan hukum berarti menegakkan Undang-Undang; namun menegakkan hukum tidak sama makna dengan menegakkan keadilan". Hukum harus dilaksanakan dan ditegakkan. Bagaimanapun hukumnya itulah yang harus berlaku, dan harus dilaksanakan serta tidak boleh menyimpang. Demikian menurut adagium fiat justicia et pereat mundus (meskipun dunia runtuh hukum harus ditegakkan), atau lex dura sedtamen scripta (hukum adalah keras, dan memang itulah bunyinya atau keadaannya, semua itu demi kepastian di dalam penegakannya). Dengan cara demikian, maka ada kepastian hukum dan kepastian hukum akan menciptakan tertib masyarakat, karena menurut Prof. Sudikno Mertokusumo tujuan hukum adalah menciptakan kepastian hukum demi ketertiban masyarakat. ${ }^{22}$

Demi kepastian hukum itulah maka ada yang berpendapat menegakkan hukum sama artinya dengan menegakkan Undang-Undang. Pendapat ini dipengaruhi oleh pandangan bahwa hukum tidak lain dari rangkaian normanorma positif dalam sistem perundangundangan. Kondisi ini tidak salah karena sistem hukum positif kita menganut atau dipengaruhi oleh sistem hukum Belanda yang sudah terbiasa dengan sistem tertulis, dan atas dasar konkordansi sistem hukum yang dibangun oleh negara indonesia memang menganut sistem hukum tertulis. Kondisi inipun tidak salah karena paham hukum tertulis sangat dipengaruhi oleh positivisme hukum yang memandang hakekat hukum tidak lain dari pada norma-norma positif dalam sistem perundang-undangan. ${ }^{23}$

Pandangan tentang hukum yang demikian itu, menurut Satjipto Rahardjo lalu menjadi bersifat optik perskriptif, yaitu memandang hukum hanya sebagai sistem kaidah yang penganalisisnya terlepas dari landasan kemasyarakatannya. dengan kata lain, ilmu hukum hanya dipandang sebagai sebuah eksemplar normologi saja untuk

21 Efendi Lotulung, "Mewujudkan Putusan Berkualitas Yang Mencerminkan Rasa Keadilan", Paparan Ketua Muda Mahkamah Agung RI Urusan Lingkungan Peradilan Tata Usaha Negara Dalam Rapat Kerja Nasional di Balikpapan, Tanggal 10 - 14 Oktober 2010.

22 Sudikno Mertokusumo, Bab-Bab Tentang Penemuan Hukum, (Bandung: Citra Adiyta, 1993), hlm 1-2.

23 Anthon F.Susanto, dalam Butir-Butir Pemikiran dalam Hukum, (Bandung: Refika Aditama, 2008), hlm.11. 
menghasilkan pola "problem solving" yang hanya menciptakan kemahiran sebagai tukang, yakni ahli-ahli hukum yang mahir menafsirkan dan menerapkan hukum positif. ${ }^{24}$

Akhirnya pandangan positivisme hukum berpengaruh terhadap kemerdekaan kekuasaan kehakiman dalam menegakkan hukum, karena hkim sebagai pelaksana kekuasaan kehakiman pada saat ia melaksanakan fungsi yudisialnya didalam memeriksa, mengadili, dan memutus perkara terikat pada penerapan hukum positif, sehingga hakim di dalam penegakan hukum sebatas berfungsi sebagai penegak undangundang.

Pandangan positivisme hukum melahirkan legisme hukum pada Hakim. Di sini peran hakim hanyalah "corong undang-undang" (la bouche des lois). la hanya subsumtie automat penerap pasal undang-undang, sehingga penegakan hukum oleh hakim dalam proses peradilan tidak sama dengan penegakan keadilan, karena hakim hanya mengedepankan kepastian hukum melalui pendekatan legalistik formal pada ketentuan undang-undang. Akibatnya dalam penegakan hukum jika hakim hanya memperhatikan kepastian hukum, maka unsur keadilan akan terabaikan, disebabkan di dalam putusannya hakim hanya menerapkan undangundang dan hasilnya adalah kebenaran formal. ${ }^{25}$

Dalam hal ini hakim harus mencari dan menemukan hukum pada undang-undang untuk diterapkan dalam peristiwa konkret yang telah dibuktikan adanya dalam proses peradilan tidak peduli apakah ketentuan hukum yang terdapat dalam pasal-pasal undang-undang yang diterapkan tersebut memenuhi rasa keadilan atau tidak, bermanfaat atau tidak bagi pencari keadilan. Secara proses hukum (peradilan) sikap hakim yang seperti itu tidak salah. Kecuali di dalamnya ada pelanggaran prosedur hukum acara yang dilakukan (unprofesional conduct) atau ada pelanggaran perilaku hakim pada saat melakukan fungsi yudisialnya (misalnya menerima suap), barulah hakim tersebut dikenai sanksi baik administrasi ataupun pidana atas kinerja dan perilakunya.

Berdasarkan penjelasan tersebut, nampak bahwa menegakkan hukum tidak sama dengan menegakkan keadilan. Putusan berkualitas tidak cukup mengandalkan kemahiran hakim dalam menafsirkan dan menerapkan undangundang, karena dalam realita kehidupan yang nyata sehari-hari, hukum tidak selalu identik dengan keadilan. Sementara itu sebagaimana telah diuraikan diatas, bagi para pencari keadilan putusan hakim yang berkualitas sama maknanya dengan putusan yang mencerminkan keadilan.

Kemerdekaan kekuasaan kehakiman berada di tangan Hakim. Sebagai penyelenggara negara di bidang yudikatif, hakim adalah penerap, penegak, dan penemu hukum. Pada waktu memutus perkara, selaku penegak hukum hakim dalam proses peradilan menerapkan hukum demi ketertiban masyarakat dan kepastian hukum. Jika hukum dalam undang-undang yang akan diterapkan (ditegakkan) tidak ditemui, hakim mencari (menemukan) atau menciptakan hukum, dan memberikan solusi hukum dalam sengketa atau perkara yang ditanganinya.

\footnotetext{
24 Satjipto Rahardjo, Pemanfaatan IImu-ilmu Sosial Bagi Pengembangan IImu Hukum, (Yogyakarta: Genta Publising, cet. 1, 2010), hlm. 35-78.

25 Lotulung, Ibid.
} 
Menurut Sudikno Mertokusumo, kepastian hukum bertujuan untuk memberikan perlindungan hukum kepada yustisiabel terhadap tindakan sewenang-wenang. Sementara itu masyarakat mengharapkan ada kepastian hukum, karena dengan ada kepastian hukum masyarakat akan lebih tertib. Hukum bertugas menciptakan kepastian hukum karena bertujuan ketertiban hukum. ${ }^{26}$ Bersamaan dengan itu, dalam penegakan hukum dan penerapan hukum, hakim harus dapat mewujudkan keadilan. Apabila ada ketentuan undang-undang yang dipakai sebagai dasar untuk menerapkan hukum atau undang-undang yang akan ditegakkan sudah tidak sesuai lagi dengan perkembangan zaman dan tuntutan rasa keadilan, atau jika undang-undang tidak mengatur, hakim wajib menggali, mengikuti dan memahami nilai-nilai hukum dan rasa keadilan yang hidup di dalam masyarakat. Melalui penegakan hukum di dalam pengadilan diharapkan putusan hakim disamping dapat mewujudkan ketertiban dan kepastian hukum, juga harus mewujudkan hukum yang memenuhi rasa keadilan. Konsekuensinya kemerdekaan kekuasaan kehakiman di tangan hakim harus dimaknai dan diimplementasikan untuk mewujudkan cita hukum yang berintikan keadilan, kemanfaatan dan kepastian hukum.

Di dalam proses yudisial pada saat menerapkan undang-undang dalam kasus konkret yang diperiksa dan diadili, Hakim harus dapat mendekatkan (menjembatani) "legal justice" dengan "moral justice", sehingga dalam proses peradilan tersebut keadilan dapat diwujudkan. Kemerdekaan kekuasaan kehakiman di tangan hakim harus diarahkan sesuai tujuan utamanya dalam proses peradilan, yakni mengadili sengketa atau perkara. Makna mengadili berarti memberi "adil" atau keadilan. Oleh karena itu putusan Hakim diberi irahirah eksekutorial "Demi keadilan berdasarkan Ketuhanan Yang Maha Esa". Tanpa irah-irah tersebut mengtikibatkan putusan hakim tidak mempunyai kekuatan hukum berlaku, sehingga tidak akan dapat dilaksanakan.

Putusan hakim yang tidak dapat dilaksanakan (non executable) atau putusan yang tidak memenuhi rasa keadilan sama artinya dengan tidak bermanfaat bagi pencari keadilan, karena tujuan yang diharapkan oleh pencari keadilan dalam beracara di pengadilan selain agar hukum dapat ditegakkan dan dengan cara itu keadilan dapat diwujudkan, namun jika oleh karena hal-hal tertentu putusan tersebut tidak dapat dilaksanakan, maka tidak akan ada manfaatnya atau gunanya bagi pihak yang bersengketa.

Dengan demikian terdapat ada benang merah dalam penegakan hukum oleh hakim melalui proses peradilan. Karena dalam penegakan hukum hakim menegakkan undangundang, namun menegakkan hukum tidak semata hanya menegakkan undang-undang. Hukum dibuat tidak semata untuk ditegakkan. Oleh karena putusan hakim tidak dijatuhkan di ruang hampa melainkan untuk memberikan keadilan maka penegakan hukum disamping untuk mewujudkan perlindungan hukum terhadap masyarakat sehingga ada ketertiban hukum, sementara itu harus dapat mewujudkan keadilan. Oleh karenanya dalam penegakannya sensitivitas hakim terhadap rasa keadilan harus dipergunakan agar dapat menjembatani antara kepastian hukum dengan rasa keadilan tersebut.

26 Ibid. 


\section{Realitas Penegakan Hukum oleh Hakim}

Realitas penegakan hukum oleh hakim, adalah suatu gambaran terhadap keadaan lingkungan sosial dimana tempat hukum berlaku dan ditegakkan. Selama ini permasalahan penegakan hukum yang benar dan adil selalu diarahkan pada penegak hukum. Penegak hukum dalam hal ini termasuk hakim dituntut untuk menjadi penegak hukum yang benar dan adil. Penegakan hukum tidak berada dalam suatu relitas yang kosong. Penegakan hukum terjadi dan berlaku di tengah-tengah kehidupan masyarakat. Lebih jauh, perlu untuk dipahami bahwa, penegakan hukum bukan sekedar berada ditengah-tengah masyrakat, melainkan dapat dipengaruhi oleh keadaan dan interaksi sosial yang terjadi dalam masyarakat.

Dalam realitas suatu masyarakat yang memelihara atau mengembangkan sistem hakhak privilege berdasarkan status atau suatu masyarakat dengan perbedaan yang tajam antara "the have" dan "the have not", atau suatu masyarakat yang berda dalam lingkungan kekuasaan otoriter, akan menampakkan sistem penegakan hukum yang berbeda dengan masyarakat yang terbuka dan egaliter. Keadaan tersebut akan sangat berpengaruh pada kemandirian dan kebebasan hakim. Dalam konteks kenyataan tersebut, menunjukan kemandirian dan independesi hakim tidak hanya ditentukan oleh susunan atau sistem kekuasaan negara, tetapi juga oleh susunan dan sistem sosial dan kemasyarakatan. ${ }^{27}$

Penegakan hukum yang benar dan adil tidak semata-mata ditentukan oleh kehendak hakim sebagai "ratu adil", tetapi juga kemauan dan kemampuan masyarakat untuk berupaya memperoleh perlakuan hukum yang benar dan adil, dengan perkataan lain bahwa, penegakan hukum yang adil ditentukan juga oleh kesadaran dan partisipasi masyarakat, bukan semata-mata keinginan hakim selaku penegak hukum.

Beberapa aspek sosial yang menggambarkan kenyataan penghambat bagi hakim dalam menegakkan keadilan dan kebenaran. Pertama; bersumber dari rasa takut atau apatime masyarakat untuk membela keadilan bagi diri sendiri maupun lingkungannya. Hal ini dapat terjadi karena susunan masyarakat yang menjelma sikap serb menerima kehendak penguasa, atau sistem penindasan yang menghilangkan keberanian untuk berjuang membela kepentingannya.

Kedua; sejak masa reformasi ketika kebebasan demokrasi dibuka lebar, terdapat berbagai tekanan publik yang acap kali berlebihan dalam penegakan hukum, tekanan tersebut berupa pengerahan massa, maupun melalui media masa cetak maupun elektronik, serta media-media sosial lainnya. Pada dasarnya, pendapat atau pandangan publik sangat diharapkan sebagai kontrol terhdap kesewenang-wenangan atau penyalahgunaan dalam proses penegakan hukum dan keadilan itu sendiri, tetapi yang harus dijaga adalah jangan sampai pendapat atau pandangan tersebut menjadi suatu tekanan yang merendahkan martabat dan kehormatan lembaga peradilan sebagai lembaga yang agung dalam menegakkan

27 Bagir Manan, Sistem Peradilan Berwibawa (Suatu Pencarian), (Jakarta: Mahakamah Agung RI, 2007), hlm. 12. 
keadilan, ${ }^{28}$ atau menimbulkan rasa takut bagi hakim dalam menjatuhkan keadilan. ${ }^{29}$

Apabila hal semacam ini terjdi, maka penegakan hukum yang benar dan adil tidak hanya dipersulit dalam suatu masyarakat yang serba berserah diri pada kehendak kekuasaan tetapi juga dalam masyarakat yang "menekan" hakim dalam menjatuhkan putusan baik atas dasarpemanfaatan kebebasan (Trial by the press) maupun karena hak-hak privilege tertentu. Publik yang menghendaki penegakan hukum yang benar dan adil harus menerima syarat untuk melakukannya dengan cara-cara yang benar dan adil juga. Publik yang menghakimi sendiri suatu peristiwa pelanggaran hukum, bukanlah cara menegakkan hukum dengan benar dan adil, melainkan suatu kekejaman yang melanggar hukum.

Selanjutnya, faktor yang ketiga sebagai penghambat dalam penegakan hukum yang benar dan adil adalah menghalalkan segala cara untuk memenangkan setiap perkara, baik perkara publik seperti tindak pidna korupsi, tindak pidana pencucian uang, tindak pidana narkoba, dan tindak pidana lainnya, maupun dalam perkara perdata dengan cara menyuap atau dengan cara memanfaatkan segala hubungan secara langsung maupun tidak langsung melalui orang lain. Kolusi atau penyuapan di lingkungan peradilan bukan suatu peristiwa yang tunggal melainkan suatu hasil kerjasama kedua belah pihak, antara penyogok dan penerima sogokan, seperti antara hakim dan pihak yang berperkara. Sebagaimana beberapa kasus yang mencuat ke permukan terjadi penagkapan beberapa advokad yang semestinya menjadi salah satu benteng penegak hukum, malah ikut terlibat dalam perbutan yang tidak terpuji.

Perbuatan-perbuatan tersebut diatas tentu merupakan suatu fakta dalam realitas kehidupan sosial kemasyarakat yang tidak terpisahkan dari penegakan hukum oleh hakim di pengadilan, sehingga tugas menegakkan hukum dan keadilan oleh hakim sangat bergantung kepada kondisi dan realitas kehidupan masyarakat disekitarnya, jika masyarakat menghendaki suatu lembaga peradilan berproses dengan baik dan benar makan, wujud keadilan akan terpancar melalui kepuasan dan kedamaian dalam menerima putusan yang dijatuhkan oleh hakim.

${ }_{28}$ Sebagai contoh tekanan tersebut dalam bentuk pengawasan secara eksternal oleh Komisi Yudisial misalnya, sesungguhnya model pengawasan yang dilakukan adalah bagaimana menjaga dan menjunjung tinggi martabat lembaga peradilan dalam bentuk pembinaan dan pengawasan yang proporsional berdasarkan kewenangan yang dimiliki terhadap terhadap kode etik dan pedoman perilaku hakim, tidak kemudian pengawasan dalam bentuk mencari-cari kelemahan dan kesalahan lembaga peradilan yang pada akhirnya meruntuhkan lembaga peradilan itu sendiri sebagai tempat pencarian keadilan. Lihat, Ismail Rumadan, "Membangun Hubungan Harmonis dalam Pelaksanaan Fungsi Pengawasan Hakim oleh Mahkamah Agung dan Komisi Yudisial dalam Rangka Menegakkan Kehormatan, Keluhuran dan Martabat Hakim", Jurnal Hukum dan Peradilan, Volume 5 Nomor 2, Juli (2016).

29 Dalam beberapa kasus korupsi tertentu seperti kasus Direktur Utama PT Merpati Nusantara Airlines, Hotasi Nababan, sesungguhnya berdasarkan beberapa bukti yang dikemukakan oleh terdakwa bahwa perbuatan tersebut masuk dalam kategori perbuatan hukum perdata, namun karena hakim sudah terpengaruh dengan tekanan publik melalui media masa maupun tekanan dalam bentuk lain, sehingga perbuatan atau tindakan tersebut diputuskan sebagai tindak pidana korupsi. Pada akhirnya MA mengabulkan permohonan kasasi jaksa penuntut umum (JPU). Hotasi divonis 4 tahun penjara dan denda 200 juta subsider 6 bulan kurungan sesuai tuntutan JPU. Sebelumnya, Hotasi divonis bebas oleh majelis hakim Pengadilan Tipikor Jakarta. Lihat, MA Batalkan Vonis Bebas Eks Dirut Merpati Perbuatan Hotasi dinilai melawan hukum dan memperkaya TALG. http://www.hukumonline.com/berita/baca/lt536cebe5083bd/ma-batalkan-vonis-bebas-eks-dirut-merpati. 


\section{Mewujudkan suatu Kedamaian dalam Putusan Hakim}

Tugas dan fungsi hakim tidak selamanya untuk memutus, fungsi hakim yang paling utama dalam menyelesaikan suatu permasalahan hukum dengan jalan bagaimana memberika perasaan damai bagi para pihak pencari keadilan, sebagaimana bunyi ketentuan dalam Pasal 130 HIR/154 RBg yang mewajibkan para hakim untuk mendamaikan para pihak yang berperkara dalam sebuah sengketa keperdataan. Peran hakim dalam konteks mendamaikan ini yang belum maksimal difungsikan, sehingga sering terdapat berbagai gejolak ditengah masyarakat yang selalu protes terhadap institusi peradilan, sebagai bentuk respon dan proses terhadap penegakan hukum di pengadilan yang dinilai tidak adil dan tidak memberikan solusi damai bagi para pencari keadilan. Protes-protes tersebut tentu sangat mempengaruhi persepsi publik akan integritas lembga peradilan sebgai lembaga yang diserahi kewenangan dalam menegakkan keadilan.

Pada posisi yang demikian tentu harus ditempuh berbagai cara untuk memperkuat peran peradilan dalam menegakkan hukum dan keadilan agar kepercayaan masyarakat terhadap lembaga peradilan dalam menyelesaiakan permasalahan hukum tetap terjaga. Terdapat beberapa syarat yang harus dipenuhi untuk memperkuat lembaga peradilan dalam mewujudkan suatu putusan yang adil dan menjamin adanya perasaan damai bagi masyarakat pencari keadilan antara lain sebagai berikut:

Pertama, aturan hukum yang akan ditegakkan. Penegakan hukum yang adil atau berkeadilan akan tercapai apabila hukum yang akan ditegakkan, demikian pula hukum yang mengatur cara-cara penegakan hukum adalah benar dan adil. Suatu aturan hukum yang dikatakan benar dan adil apabila dibuat dengan cara-cara yang benar dan materi muatannya sesuai dengan kesadaran hukum dan memberi sebesar-bebesarnya manfaat bagi kepentingan orang perorangan dan masyarakat banyak pada umumnya. Suatu aturan hukum akan tidak benar dan tidak adil apabila hanya dibuat untuk kepentingan kekusaan belaka dan mengandung kesewenang-wenangan. Namun perlu juga mendapat perhatian, bahwa suatu suatu hukum dapat menjadi tidak benar dan tidak adil apabila mempunyai jarak begitu jauh dengan kesadaran dan kenyataan sosial yang berlaku. Sehingga rakyat merasa asing atau terasing dengan aturan hukum tersebut. Selanjutnya hukum dapat pula tidak adil apabila pembuatnya tidak mengindahkan tata cara pembuatan peraturan yang baik, karena akan menimbulkan keadaan seperti kerancuan dalam penerapan atau ketidakpastian hukum.

Kedua, hakim sebagai pelaku penegak hukum, hakim dapatlah disebut sebagai kunci utama dalam menegakkan hukum yang adil dan berkeadilan, di tangan hakim, atauran hukum yang bersifat abstrak menjadi konkret, berlaku terhadap pencari keadilan. Terdapat beberapa syarat agar hakim dapat menegakkan hukum secara adil. ${ }^{30}$

a. Perlakuan terhadap hukum yang akan ditegakkan. Ada pilihan peranan yang dpat dilakukan hakim dalam menegakkan hukum, (1) hakim sekedar sebagai "la bouche de la Ioi" atau "spreekbuis van de wet". Dalam

30 Bagir Manan, Ibid. 
hal aturan hukum sudah jelas hakim hanya bertindak sebagai corong undang-undang, kecuali penerapan itu menimbulkan ketidakadilan, bertentangan dengan kesusilaan, atau bertentangan dengan kepentingan umum dan ketertiban umum.

(2) hakim berlaku sebagai penerjemah (interpreter) suatu aturan hukum agar suatu aturan hukum dapat menjadi intrumen keadilan, dan (3) hakim dapat menjadi pencipta hukum (rechtsschepping), dalam hal hukum yang ada tidak cukup mengatur atau didapati kekosongan hukum. ${ }^{31}$

b. Memperhatikankepentinganataukebutuhan masyarakat baik kebutuhan nyata maupun proyeksi kebutuhan di masa depan. Hukum adalah instrumen sosial untuk menjaga dan membangun masyarakat. Hukum tidak boleh mengandung kesenjangan dengan kenyataan yang hidup ditengah masyarakat. Hakim dalam menegakkan hukum tidak mengindahkan berbagai kenyataan dan kebutuhan masyarakat, akan dirasakan sebagai sesuatu yang asing bahkan mungkin menekan kehidupan masyarakat. Menegakkan hukum yang asing bagi suatu masyarakat dapat dipandang sebagai suatu bentuk penegakan hukum yang tidak adil atau berkeadilan. ${ }^{32}$

Ketiga, lingkungan sosial sebagai tempat hukum berlaku. Penegakan hukum oleh hakim sangat dipengaruhi oleh kenyataan-kenyataan, baik sosial, ekonomi, politik maupun budaya. Meskipun dalam situasi tertentu, hukum dapat berperan sebagai sarana pembaharuan, tetapi dalam banyak hal hukum adalah cerminan masyarakat. Telah dikemukakan bahwa, tekanan publik terhadap penegakan hukum dapat mempengaruhi putusan hakim. Begitu pula kepentingan-kepentingan tertentu seperti kepentingan ekonomi dan politik yang dominan dapat menentukan wujud dari putusan hakim. Oleh sebab itu perlu diciptakan berbagai persyaratan sosial yang kondusif agar penegakan hukum dapat dilaksanakan secara benar dan adil.

Persyaratan tersebut antara lain tumbuhnya prinsip egalitarian, keterbukaan untuk menciptakan berbagai keseimbangan dalam berbagai perikehidupan masyarakat. Dalam berbagai perbedaan yang begitu tajam, baik sosial, ekonomi, politik dan lain-lain, akan dialami kesulitan untuk menciptakan sistem penegakan hukum yang benar dan adil, karena penegak hukum akan berpihak pada kekuatan kekuatan dominan yang mungkin tidak berpihak pada kebenaran dan keadilan. Hukum yang benar dan adil hanya dapat berperan dalam tatanan yang berkeseimbangan dan tidak dalam tatanan ekstimitas tertentu. ${ }^{33}$

Selanjutnya, untuk menjaga dan mewujudkan suatu putusan hakim yang adil dan mendapat respon yang penuh kedmaian dari para pencari keadilan, terdapat dua aspek penting yang harus dilaksanakan, yaitu terkait dengan tata cara penegakan hukum (prosedural justice) dan ini atau hasil dari penegakan hukum itu sendiri (substantive justice).

Pada masyarakat yang menjunjung tinggi hukum, persoalan tata cara mewujudkan tujuan sama pentingnya dengan tujuan itu

\footnotetext{
Bagir Manan, Ibid.

Ibid.

Bagir Manan, Sistem Peradilan Berwibawa ibid., hlm. 12.
} 
sendiri. Tujuan mewujudkan keadilan hanya dapat ditempuh dengan cara yang adil pula. Cara yang dimaksud meliputi, kepastian peran kelembagaan, dan kepastian mekanisme. Inilah yang disebut dengan kepastian hukum (rechtszekerheid). Pada prinsipnya kepastian memang tidak sama dengan keadilan, bahkan dapat bertolak belakang antara kepastian dan keadilan, namun tanpa kepastian, pasti tidak akan ada keadilan. Keadilan dalam ketidakpastian akan menjadi sangat subjektif karena sepenuhnya tergantung pada hakim yang mengendalikan kepastian. Perwujudan keadilan semacam ini berpotensi melahirkan ketidakadilan, sehingga wujud kedamaian menjadi tidak tampak bagi salah satu pihak yang merasa tidak diberlakukan secara adil.

Selanjutnya terkait dengan substantive justice, menyangkut isi keadilan itu sendiri. Secara teoritik, banyak pandangan mengenai hal ini. Ada yang melihat dari tingkat pencapaian kepuasan (Rescoe Pound). Ada yang memandang dari sudut manfaat (Bentham), dan ada pula yang memandang dari perspektif keadilan semata-mata diukur dari pelaksanaan hukum itu sendiri (Hans Kelsen). Untuk dapat menemukan secara tepat susbtansi keadilan, haruslah dibedakan anatara keadilan individual (individual justice) dan keadilan sosial (soscial justice). Sangat ideal apabila keadilan individual tercermin dalam keadilan sosial atau sebaliknya keadilan sosial menjadi tidak lain dari sublimasi keadilan individual. ${ }^{34}$ Namun pada kenyataannya terdapat gep antara keadilan individual dan keadilan sosial. Gep ini dapat diatasi apabila dalam sistem penegak hukum dapat dengan cermat diletakkan nilai sosial atau moral dari setiap aturan hukum. Dengan demikian dalam setiap keadilan individual akan terkandung keadilan sosial. Harmoni antara keadilan sosial dan individual yang diterapkan melalui putusan pengadilan tentu dapat menghadirkan suasana kedamaian bagi masyarakat pencari keadilan.

\section{Penutup}

Di tengah suasana pengaruh dan tekanan kekuasaan dalam segala aktivitas kehidupan di tengah masyarakat baik aktivitas individual, aktivitas sosial ataupun aktivitas publik, institusi pengadilan sebagai lembaga yang dijamin indepensinya dalam menegakkan hukum dan keadilan masih dipengaruhi oleh kekuatan dan kekuasaan lain, terutama pengaruh kekuasaan eksekutif dan kekuatan politik, fungsi penegakan hukum oleh pengadilan belum sepenuhnya mandiri, sehingga tugas utama pengadilan untuk mewujudkan keadilan dan kedamaian ditengah masyarakat masih jauh dari harapan. Oleh karena itu perlu untuk diperkuat institusi pengadilan sebagai benteng terakhir pencari keadilan untuk menghadirkan suasana dan perasaan damai bagi pencari keadilan. Penguatan lembaga peradilan tersebut dapat berupa; ketentuan dan aturan hukum yang mengatur cara-cara menegakkan hukum dan keadilan itu tersusun dengan baik dan benar secara pasti. Kemudian kontrol berupa pengawasan terhadap institusi peradilan untuk lebih transparan dan objektif dalam meneyelsaikan suatu sengketa hukum dipengadilan perlu untuk dilakukan secara proporsional dan profesional, dan selanjutnya budaya masyarakat yang terkait proses hukum harus memahami posisi dan kedudukannya sebagai elemen terpenting bagi tegaknya hukum dan keadilan.

$34 \quad$ Bagir Manan, Op.cit., hlm. 12-13. 
Selanjutnya, untuk menjaga dan mewujudkan suatu putusan hakim yang adil dan mendapat respon yang penuh kedmaian dari para pencari keadilan, terdapat dua aspek penting yang harus dilaksanakan, yaitu terkait dengan tata cara penegakan hukum (prosedural justice) dan ini atau hasil dari penegakan hukum itu sendiri (substantive justice). Prosedural justice berkaitan dengan aspek kepastian hukum dalam proses penegakan hukum di pengadilan, dan substantive justice terkait dengan putusan pengadilan atau hakim yang dapat menghilangkan gap antara keadilan individual dengan keadilan sosial dengan cermat diletakkan nilai-nilai sosial atau moral dari setiap aturan hukum, dengan demikian dalam setiap keadilan individual akan terkandung keadilan sosial. Harmoni antara keadilan sosial dan individual yang diterapkan melalui putusan pengadilan tentu dapat menghadirkan suasana kedamaian bagi masyarakat pencari keadilan.

\section{Daftar Pustaka}

\section{Buku}

Bakir, Herman, Filsafat Hukum, Tema-Tema Fundamental Keadilan dari Sisi Ajaran Fiat Justitia Ruat Caelum, (Yogyakarta: Pustaka Pelajar, 2015)

Dewantara, Nanda, Masalah Kebebasan Hakim Dalam Menangani Suatu Perkara Pidana, (Jakarta: Aksara Persada Indonesia, Cet. II, 1987)

Friedman, Lawrence M., Teori dan Filsafat Hukum, (Jakarta: PT. Rajawali Press, 1990)

Friedman, Lawrence M., The Legal System : A Social Science Perspective, (New York: Rusell Sage Foundation, 1975)

Manan, Bagir, Sistem Peradilan Berwibawa (Suatu Pencarian), (Jakarta: Mahkamah Agung RI, 2007)

Montesquieu, The Spirit of The Law, transleted by Thomas Nugent, (New York: Hafner Press, 1949)

Muchsan, Hukum Tata Pemerintahan, (Yogyakarta: Penerbit Liberty, 1985)

Mujahidin, Ahmad, Peradilan Satu Atap di Indonesia, (Bandung: Refika Aditama, 2007)
Rahardjo, Satjipto, Membedah Hukum Progresif, (Jakarta: Kompas, 2007)

Rahardjo, Satjipto, Pemanfaatan IImu-ilmu Sosial Bagi Pengembangan IImu Hukum, (Yogyakarta: Genta Publising, 2010)

Sujata, Antonius, Reformasi Dalam Penegakan Hukum, (Jakarta: Djambatan, 2000)

Wasitaatmadja, Fokkey Fuad, Filsafat Hukum, Akar Religiositas Hukum, (Jakarta: Prenadamedia Group, 2015)

\section{Makalah/Artikel/Laporan/Hasil Penelitian}

Dwisvimiar, Inge, "Keadilan Dalam Perspektif Filsafat IImu Hukum", Jurnal Dinamika Hukum, vol; 1, No. 3 September (2011)

Husni, M., "Moral dan Keadilan Sebagai Landasan Penegakan Hukum Yang Responsif", Jurnal Equality Fakultas Hukum Universitas Sumatera Utara, Vol. 11 (1) Februari (2006)

Indarti, Erlyn, "Demokrasi dan Kekerasan: Sebuah Tinjauan Filsafat Hukum", Aequitas Juris, Jurnal Fakultas Hukum Universitas Katolik Widya Mandira Kupang, Vol. 2 (1), (2008)

Lotulung, Efendi, "Mewujudkan Putusan Berkualitas Yang Mencerminkan Rasa Keadilan", (makalah dalam Rapat Kerja Nasional di Balikpapan, Tanggal 10 - 14 Oktober 2010)

Manan, Bagir, "Organisasi Peradilan di Indonesia", (makalah Penataran Hukum Administrasi Tahun 1997/1998, Pelaksanaan Program Kerjasama Hukum Indonesia-Belanda, Penyelenggara Fak. Hukum Airlangga, Surabaya, 12 Februari, 1998)

Maryanto, "Refleksi dan Relevansi Pemikiran Filsafat Hukum Bagi Pengembangan IImu Hukum", Jurnal Hukum, Fakultas Hukum Universitas Islam Sultan Agung Semarang, Vol. 13 (1) (2003)

Rumadan, Ismail, "Membangun Hubungan Harmonis dalam Pelaksanaan Fungsi Pengawasan Hakim oleh Mahkamah Agung dan Komisi Yudisial dalam Rangka Menegakkan Kehormatan, Keluhuran dan Martabat Hakim", Jurnal Hukum dan Peradilan, Volume 5 Nomor 2, Juli (2016)

Susanto, Anthon F., "Keraguan dan Ketidakadilan Hukum (Sebuah Pembacaan Dekonstruktif)", Jurnal Keadilan Sosial, Edisi 1 tahun (2010)

\section{Internet}

Amin, M., "Kebenaran Hukum Vs Keadilan Masyarakat", tersedia di website http://www. Pa-lubukpakam. net/artikel/186-kebenaran- 
hukum-vs-keadilan- masyarakat.html. (diakses 9 Februari 2017)

Nur Rahmah, Amelinda, "Keadilan di Dalam Lembaga Hukum", http://www.kompasiana. com/amelindanurrahmah/keadilan-di-dalamlembaga-hukum, (diakses 9 Februari 2017) 
"Halaman ini dikosongkan" 